\title{
Research on the Current Situation and Development of Fuel Cell Powered Transportation
}

\author{
HAO SU* \\ NANTONG COSCO KHI ENG.CO.,LTD, Nantong, China, 226000
}

\begin{abstract}
Traditional oil consumed transportation including vehicles and vessel produces green house gases, which is not environmentally-friendly. As a new type of energy-consumed unit, the fuel cell is popular due to its less emission level, high efficiency and low noise. This paper introduces the principle and characteristics of fuel cell, with further introduction to the application status of fuel cell system in the vehicle and maritime industry. Further aspects that need to be improved will be discussed and analyzed, in order to promote fuel cell system in transportation area in a large scale. It can be clearly seen that various factors (infrastructure, cost, durability, etc.) should be considered in the near future.
\end{abstract}

\section{Introduction}

\subsection{Background}

With the increasing demand for sustainable and environmental-friendly society, more governments and organizations have enacted stricter laws and legislation about emissions of greenhouse gases (GHGs), especially in the transportation area, since the carbon emissions are produced from vehicles and engines account for a large proportion. The global emission in a specific year is shown in Figure 1 by source and fuel type.

It is illustrated from the diagram that transport operations account for 16 percent of all human-made
With the increasing demand for sustainable and environmental-friendly society, more governments and organizations have enacted stricter laws and legislation about emissions of greenhouse gases (GHGs), especially in the transportation area, since greenhouse-gas emission, which seems to have great potential for carbon reduction.

Due to the importance of decreasing carbon emission, the IMO (International Maritime Organization) has set a GHG (Global greenhouse gas) strategy, which indicates totally at least $50 \%$ of GHG emission reduction in 2050 compared to that in 2008 [2]. In addition, the emission standard of vehicles in China is updated to VI, which sets a lower limitation for carbon dioxide and particulars [3].

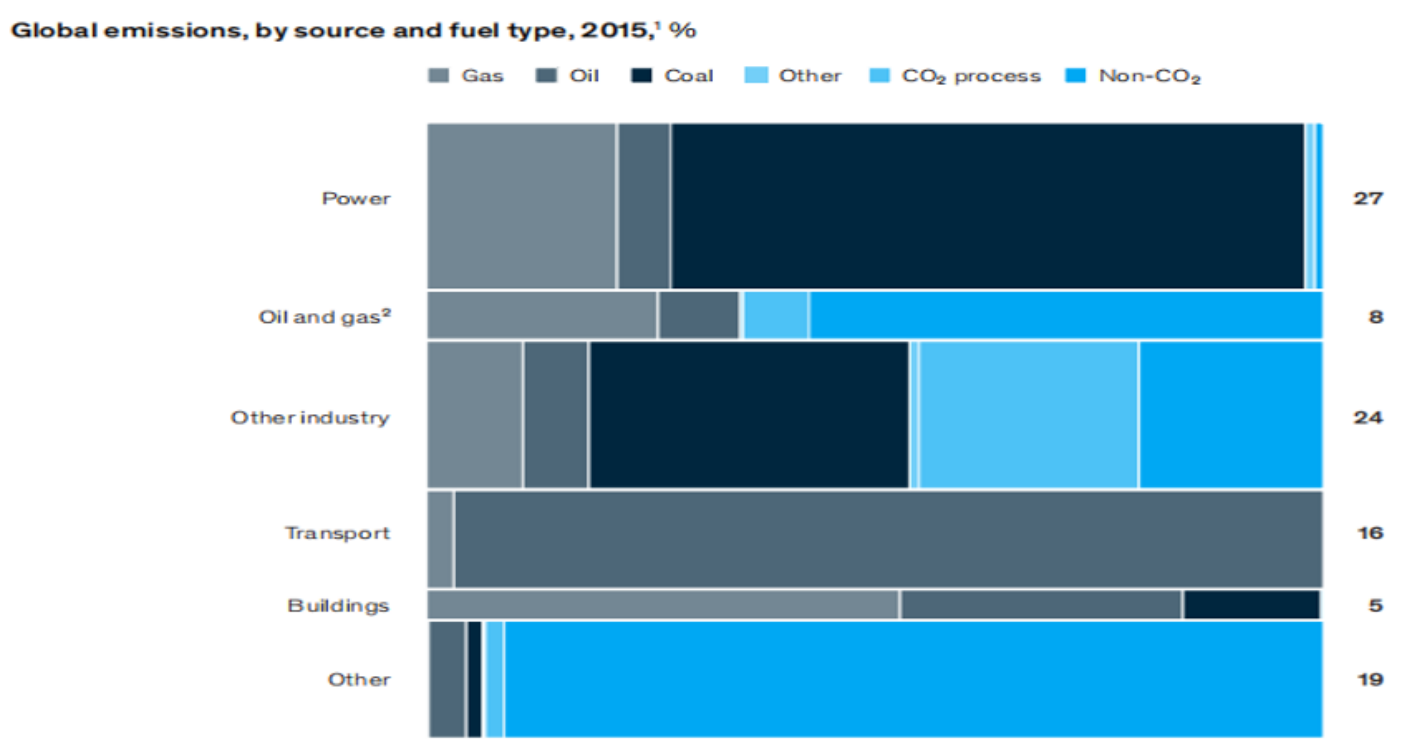

Fig.1. Global emission, by source and fuel type in 2015 [1]

\footnotetext{
*Corresponding author: suhao77@126.com
} 


\subsection{Principle}

Compared with traditional energy (oil, coal and etc.), fuel cell system, which converts the chemical energy of hydrogen or other fuels into electricity and is promising energy applied in transportation, since it is renewable with high energy-density and relatively fewer carbon emission [4]. The principle of fuel cell system is quite simple, Figure 2 demonstrates the reaction of alkaline fuel cell in anode and cathode.

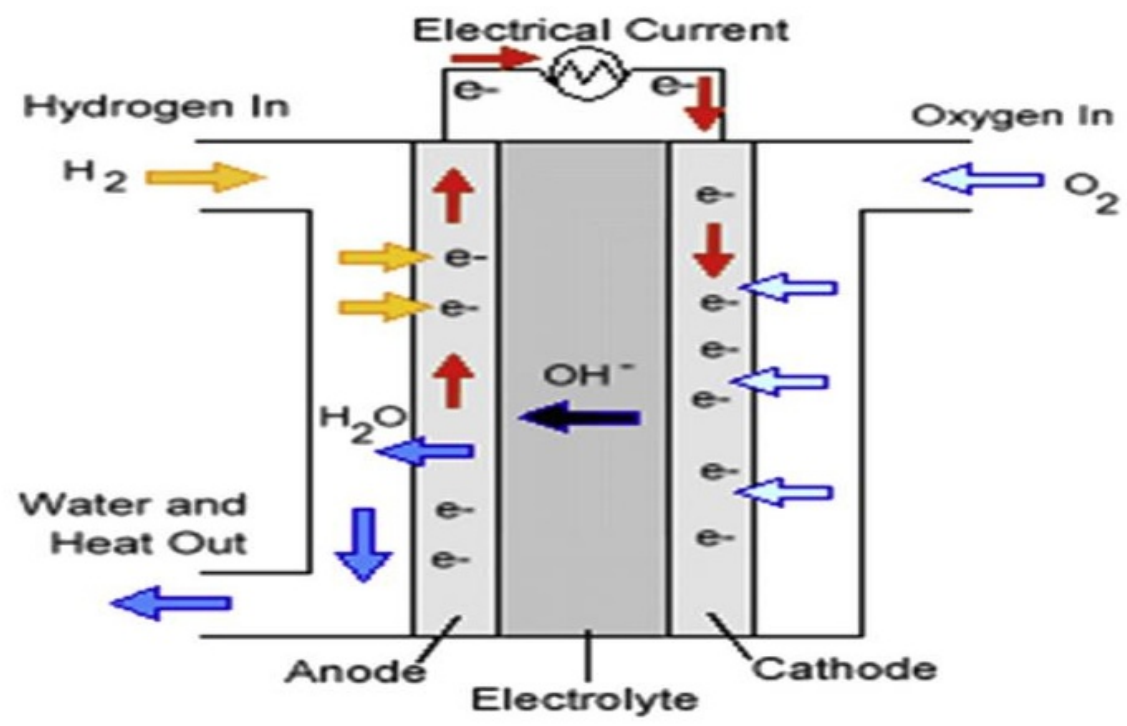

Fig. 2. Alkaline fuel cell [5]

\subsection{Characteristics}

Fuel cells can be classified into different types. In the case of electrolyte types, there are AFC, PAFC, PEMFC, MCFC and SOFC. The main characteristics of these fuel cells are demonstrated in Table 1.

If the fuel cell is applied in the car and shipping industry as a power generation system, it shall have high efficiency of electricity generation, together with the quick dynamic response for various external loads to produce stable propulsion power. Besides, it will be better to utilize waste heat, especially for the vessel.
Lastly, the safety and size arrangement shall also be considered. At present, the PEMFC is widely used in the vehicle industry due to its quick response and zero carbon emission [7], while fuel cells applied in the shipping industry develop at a steady pace.

Therefore, the fuel cell technology applied in both two areas will be reviewed below, and further possible ways to improve the development of fuel cells in China will be discussed.

Table 1. Summary of characteristics for fuel cells $[4,6]$

\begin{tabular}{|l|l|l|l|l|l|}
\hline Fuel cell $* 1$ & \multicolumn{1}{|c|}{ AFC } & \multicolumn{1}{|c|}{ PAFC } & PEMFC & MCFC & SOFC \\
\hline $\begin{array}{l}\text { Operating } \\
\text { temperature }\end{array}$ & $\left(50-200^{\circ} \mathrm{C}\right)$ & \multicolumn{1}{|c|}{$\left(100-200^{\circ} \mathrm{C}\right)$} & $\left(60-130^{\circ} \mathrm{C}\right)$ & \multicolumn{1}{|c|}{$\left(650-700^{\circ} \mathrm{C}\right)$} & $\left(800-1000^{\circ} \mathrm{C}\right)$ \\
\hline Merits & $\begin{array}{l}\text { clean, high } \\
\text { efficiency, } \\
\text { low cost }\end{array}$ & $\begin{array}{l}\text { clean, low } \\
\text { noise, stable }\end{array}$ & $\begin{array}{l}\text { clean, low } \\
\text { noise, quick } \\
\text { start }\end{array}$ & $\begin{array}{l}\text { low cost, } \\
\text { hydrocarbon fuel, } \\
\text { exhaust heat reuse }\end{array}$ & $\begin{array}{l}\text { low cost, } \\
\text { hydrocarbon fuel, } \\
\text { exhaust heat reuse }\end{array}$ \\
\hline Demerits & $\begin{array}{l}\text { pure } \\
\text { hydrogen, } \\
\text { pure oxygen }\end{array}$ & $\begin{array}{l}\text { high cost, low } \\
\text { efficiency }\end{array}$ & $\begin{array}{l}\text { high cost, } \\
\text { high purity } \\
\text { hydrogen }\end{array}$ & $\begin{array}{l}\text { slow start, high } \\
\text { corrosion }\end{array}$ & $\begin{array}{l}\text { slow start, high } \\
\text { requirement for } \\
\text { material }\end{array}$ \\
\hline Electricity & $60 \%-70 \%$ & $37 \%-42 \%$ & $43 \%-58 \%$ & $>50 \%$ & 50\%-65\% \\
\hline $\begin{array}{l}\text { Application } \\
*^{3}\end{array}$ & Space & $\begin{array}{l}\text { Electrical } \\
\text { power }\end{array}$ & $\begin{array}{l}\text { Car, } \\
\text { submarine }\end{array}$ & $\begin{array}{l}\text { Electrical power } \\
\text { generation and }\end{array}$ & $\begin{array}{l}\text { Electrical power } \\
\text { generation }\end{array}$ \\
\hline
\end{tabular}




\begin{tabular}{|c|c|c|c|}
\hline & generation & co-generation & \\
\hline Remarks & \multicolumn{3}{|c|}{$\begin{array}{l}\text { *1 }^{1} \text { AFC: Alkaline Fuel Cell } \\
\text { MCFC: Molten Carbonate Fuel Cell PEMFC: Proton Exchange Membrane Fuel Cell } \\
\text { SOFC: Solid Oxide Fuel Cell } \\
*^{2} \text { The index of electricity efficiency is the global performance which includes possible } \\
\text { thermal performance. } \\
*^{3} \text { The applications of these fuel cells listed are main applications. }\end{array}$} \\
\hline
\end{tabular}

\section{Research Status}

\subsection{Automobile}

When it comes to the utilization of fuel cell in vehicles, the cost and duration are two main factors need to be considered [8], which has been studied and improved a lot.

The technology of fuel cell in Japan and Korea is advanced around the globe, several major automobile companies, such as Toyota, Hyundai and Honda, have carried out in-depth research on improving the durability and reducing the cost of PEMFC. The most representative is the hydrogen fuel cell vehicle Mirai launched by Toyota in 2014 according to the FCV (fuel cell vehicle) plan [6]. Meanwhile, Honda has been working on fuel cell technology since 1996 and Clarity Fuel Cell is its first officially sold fuel cell car, currently on the market for JPY $¥ 7.66 \mathrm{~m}$ [9]. Besides, the world famous company Ballard is considered to be the pioneer of fuel cell company and has become the first one to serve more than ten million kilometers in public bus service. [10]

Table 2 lists the main performance of typical fuel cell vehicle compares with that burns with traditional petrol.

Table 2. Comparison of fuel cell vehicle with traditional vehicle $[6,9]$

\begin{tabular}{|l|c|c|}
\hline Technical index & Honda Clarity & Honda Accord (18 2.0L E-CVT) \\
\hline Vehicle mass/ton & 1.6 & 1.5 \\
\hline Fuel cell power/kW & 100 & 107 \\
\hline Acceleration time/s & 11 & 8.8 \\
\hline Duration/km & 570 & $>600$ \\
\hline Maximum speed/(km/h) & 160 & 190 \\
\hline
\end{tabular}

It can be seen from the comparison chart that the power output of fuel cell vehicles can be matched with traditional car, while speed performance including acceleration time and maximum speed is inferior to traditional car.

While the development of hydrogen vehicle in China has seen great progress, compared with that in 2008 . More specifically, there are more than 2700 hydrogen vehicles sold in China in 2019, which increases nearly $80 \%$ of that in the previous year, not to mention that there are only fewer hydrogen vehicles in 2008 , which is mainly used as a commercial demonstration. [11]

In Table 3, the representative hydrogen vehicle developed in China is roughly contrasted with that made in other countries to reveal the development level.

From Table 3, we can see that the power generated for fuel cell vehicles in China is relatively small compared to other fuel cell makers, while durability is one major issue that should be developed to meet the international level.

Table 3. Comparison of fuel cell vehicle with traditional vehicle [11]

\begin{tabular}{|l|c|c|c|c|}
\hline Maker & $\begin{array}{c}\text { Rated power } \\
(\mathrm{kW})\end{array}$ & $\begin{array}{c}\text { Mass power density } \\
(\mathrm{W} / \mathrm{kg})\end{array}$ & $\begin{array}{c}\text { Start-up at cold condition } \\
\left({ }^{\circ} \mathrm{C}\right)\end{array}$ & $\begin{array}{c}\text { Durability } \\
(\mathrm{h})\end{array}$ \\
\hline Ballard & $70 / 85 / 100$ & $280 / 330 / 350$ & -30 & $>30000$ \\
\hline
\end{tabular}




\begin{tabular}{|l|c|c|c|c|}
\hline US Hybrid & $40 / 80 / 120$ & 270 & $-30 /-40 /-25$ & $>10000$ \\
\hline Hydrogenics & $60 / 93 / 128$ & $220 / 258 / 275$ & -10 & $>10000$ \\
\hline $\begin{array}{l}\text { SinoHytec } \\
\text { (Beijing) }\end{array}$ & $31.3 / 65 / 75$ & $230 / 250 / 302$ & -30 & $<5000$ \\
\hline
\end{tabular}

\subsection{Vessel}

The research on fuel-cell power generation system of ships is still in a small scale compared with vehicles. It should be noted that not only one kind of fuel cell is applied as propulsion power or electrical generation.

To begin with, the HDW works in cooperation with Siemens to provide PEMFC to be employed in submarines, with the system consists of nine Simens 30kW-50kW PEMFC modules. [12] Besides, In November 2020, South Korean company Doosan announced the plan to develop SOFC power generation systems at $620^{\circ} \mathrm{C}$ in cooperation with company Nabig8. [13] Other shipyards, such as Samsung Heavy Industries and Bloom Energy, are jointly developing SOFC fuel cell powered ships, being expected to develop core fuel cell technologies for LNG, shuttle Tanks and other ship types by the end of 2022. [14] Moreover, German cruise ship AIDAnova will carry the methanol fuel cell system developed by FST, which is expected to be installed and tested in 2021. [15]

In view of development status in China, the Wuhan institute of Marine electric propulsion system has released the national first grade $500 \mathrm{~kW}$ Marine fuel cell solutions at Shanghai Maritime Exhibition in 2019, filled the domestic blank in this field. [16]

\section{Further research and improvement in China}

\subsection{Automobile}

To promote the application of fuel cell vehicles in China, it is necessary to take into account several key factors.

\subsubsection{Infrastructure}

The number of $\mathrm{H} 2$ stations reflects the development of fuel cell vehicle to some extent. However, the shortage of $\mathrm{H} 2$ stations in China has been an obstacle to the development of the hydrogen industry. Although the number of stations constructed or under constructed in 2019 is more than 4 times that in 2017 (61 and 14 respectively), it is still away from developed countries (114 in Japan and 87 in Germany) leading in this field. [17]

Meanwhile, the safety standard system including the guidance of hydrogen transportation, technical specifications for the H2 station shall be established, since the development of a safety standard system can be a great support to the design of advanced fuel cell vehicle. In this field, Japan has established an advanced and complete standard system, which is a good example for reference.

\subsubsection{Cost}

Due to the application of expensive rare metals Pt to increase electrochemical kinetics, the cost of PEMFC powered vehicle is relatively high, which has surely hindered the promotion of hydrogen vehicle in China. Therefore, it is meaningful to decrease the capital cost.

In case of lowering Pt loading of catalyst, one way is to manufacture alloy of Pt and nonmetals catalyst like $\mathrm{Pt} / \mathrm{C}$ with nanoscale CNT(carbon nano tube) to increase the catalytic activity. [18] Besides, constructing a core-shell structured $\mathrm{PdPt} @ \mathrm{Pt} / \mathrm{C}$ shows high performance with low Pt loading. [19] Last but not least, it may be possible to replace Pt totally with nonmetals to decrease the cost of fuel cell significantly. As a new material, graphene is possible to be used as a catalyst in fuel cell due to its special structure and high performance of chemistry and thermodynamics stability. [20]

\subsubsection{Durability}

Durability is one major issue that should be coped with for hydrogen vehicle. The general system durability is 2500 hours, which is far away from the target 5000 hours. Owing to the various transient loading conditions (i.e. frequent start-ups/shut-downs, speed-ups/speed-downs, massive load cycles), the corrosion of catalyst support, coarsening of catalyst $\mathrm{Pt}$, and decomposition of the membrane, ECSA (Electrochemical Active Surface Areas) attenuates gradually and thus the performance of system degrades. [21]

The fuel cell failure can be mitigated in several ways. For instance, applying more stable catalyst support can be effective to reduce corrosion. Besides, strengthening bonding force between metal particles and support indicates to be an improved system control strategy. What is more, studying an enhanced membrane can increase mechanical performance and thermal stability, and thus the degradation of exchanged membrane can be slow down.

In a word, infrastructure, cost and durability are three main factors that need to be considered for hydrogen vehicle. Building more $\mathrm{H} 2$ stations, studying the economical material to replace expensive catalyst Pt and applying stable catalyst support can be effective ways to improve system performance and will be of great importance to promote the development of hydrogen driven automobile in China and other countries.

\subsection{Vessel}


In case of promoting the application of the fuel cell system in maritime industry on a large scale, it is still a long way to go through for China and other countries. Unlike PEMFC applied in vehicle, which is a mature technology, it is necessary to take into account some characteristics according to the different deadweight and various types of vessels when applying fuel cell in ships.

\subsubsection{Arrangement}

In view of the target of energy conservation and emission reduction in shipping industry, hydrogen fuel cell like PEMFC has huge market potential. However, due to the low energy density, the capacity of hydrogen tank tends to be big, which may eventually influence the capacity of the cargo tank in a bulk carrier or the number of tourists on a cruise ship. It is a problem about which side to be sacrificed: endurance or loading quantity.

Studying the high efficiency of hydrogen storage material is necessary to solve the problem of storage and transportation. There are some materials under investigation including magnesium based, carbon based and nanometer hydrogen storage materials, which are with high prospect and potential. [22]

Besides, since hydrogen gas is flammable and explosive, it is crucial to distinguish hazard areas from the accommodation area and cargo area when considering tank arrangement.

\subsubsection{Cost}

Cost is another key index that should be given full consideration. Compared to the internal combustion engine, the cost of fuel cell is high. Therefore, high-temperature fuel cells SOFC and MCFC have great potential, since expensive catalyst is no need, and hydrocarbon fuel can be consumed, while the excess heat can also be utilized. Studying stable cell components to avoid corrosion and lowering the cost of fuel cell system is needful in order to promote the application of fuel cell.

\subsubsection{Infrastructure}

Basic H2 station in port should be built in order to provide sufficient hydrogen for ocean ships. While considering the lack of safety standard and regulation towards fuel cell, the IMO and other organizations are supposed to establish safety standard about transportation and storage in ship, while the guidance of auxiliary system including co-generating system utilizing excess heat shall be investigated.

To sum up, arrangement, cost and infrastructure are the main challenges when applying fuel cell in ship on a large scale. While the decrease of the cost of key fuel cell modules and the establishment of a comprehensive system including arrangement guidance and safety standard will surely contribute to the development of fuel cell system.

\section{Conclusion}

Fuel cell system applied in the transportation area seems to be very attractive due to its low emission level and high efficiency, which is more potential than traditional internal combustion engines.

The application status in the vehicle is relatively mature, since hydrogen based PEMFC is mainly used with the tendency to cost down capital and longer durability. However, several characteristics such as infrastructure, cost and durability are key factors that need to be well considered. With the help of constructing more H2 stations, studying replaceable cheaper catalyst material and more stable support tend to promote the application fuel cell in the automobile industry.

Compared to the vehicle, the application status in maritime industry is in a small scale. The features of different fuel cell are suitable for specific offshore structures. To be specific, PEMFC is applied mainly on submarine with the higher requirement of invisibility, while high operating temperature fuel cell systems like MCFC and SOFC have great potential in large ocean-going ships. The cost, infrastructure and arrangement are main factors and of great importance to promoting the application of fuel cell systems on a large scale.

I would like to give my sincere gratitude to all my teachers with extraordinary patience and consistent encouragement. They gave me great help by providing me with advice of great value and inspiration for new ideas.

\section{References}

1. Chantal B, Sahar R, Occo R, Eveline S. The future is now: How oil and gas companies can decarbonize. January 2020.

2. DNVGL. Maritime forecast to 2050 Energy Transition Outlook 2050. August 2020.

3. Lin F. CN-6 Challenges and Delphi EMS Solutions. Jun 2016.

4. Yi B. Fuel cell: fundamental, technology and prospect. Chinese Battery Industry. February 2003.

5. GreenHome. http://www.scgh.com/featured/fuel-cells-101/.

6. Li J, Fang C, Xu L. Current status and trends of the research and development for fuel cell vehicles. J. Automotive Safety and Energy, 2004, Vol.5 No.1.

7. Fang C. Research on the Control System for Vehicular PEM Fuel Cell Engines. May 2014.

8. Shao Z, Yi B. Developing Trend and Present Status of Hydrogen Energy and Fuel Cell Development. 10.16418/j.issn.1000-3045.2019.04.012.

9. Honda. http://www.honda.com.cn/honda/news/list/2016122 0.html.

10. Ballard. https://cn.ballard.com/markets/transit-bus. 
11. China EV100. China Hydrogen Industry Development Report 2020. October 2020.

12. Jose J, Carlos A, Carlos F, Luis C. Analysing the possibilities of using fuel cells in ships. http://dx.doi.org/10.1016/j.ijhydene.2015.11.145.

November 2015.

13. Fuel Cells Bulletin. Doosan and Navig8 to develop marine system with Ceres SOFC unit. https://doi.org/10.1016/S1464-2859(20)30575-7. December 2020.

14. Fuel Cells Bulletin. Bloom Energy joins with Samsung Heavy for clean ship power. https://doi.org/10.1016/S1464-2859(20)30284-4. July 2020.

15. Fuel Cells Bulletin. Freudenberg fuel cell tech for maritime project in Germany. https://doi.org/10.1016/S1464-2859(19)30467-5. November 2019.

16. Marintec.

http://www.china-hydrogen.org/?newslist-llyy/1234 6.html.December 2019.
17. Fan H. Overview of Hydrogen fuel cell Vehicle development in China in 2019. December 2019.

18. Wu Y. Preparation and Investigation of High Performance and Low-Pt Loading Catalysts for Fuel Cell Application. April 2010.

19. Wu Y, Liao S, Guo H, Hao X. Preparation of high-performance PdPt-Pt core-shell catalyst with shortened carbon nanotubes as support. August 2013.

20. Muhammad Z, Saman S, Abbas K, Syed S, Mohammad K. Recent developments in graphene based noval structures for efficient and durable fuel cells. February 2020.

21. Li W, Lane A. Resolving the HUPD and HOPD by DEMS to determine the ECSA of Pt electrodes in PEM fuel cells. September 2011.

22. Zhu Z. The Research of a Fuel Cell Powered Propulsion System and the Hydrogen Storage Method on a Typical Ship. June 2015. 